\title{
Isotopic Studies Of Minerals and Their Host Kimberlites from Australia and Southern Africa
}

\author{
Steven A. Cooper ${ }^{1,2}$, Y.A. Kostitsyn ${ }^{3}$, Elena A. Belousova ${ }^{1}$, \& W.L. Griffin ${ }^{1}$ \\ ${ }^{1}$ GEMOC ARC National Key Centre, Macquarie University, NSW, 2109, Australia \\ ${ }^{2}$ Orogenic Exploration Pty Ltd, Burwood, Vic, 3125, Australia \\ ${ }^{3}$ Laboratory of Isotopic Geochemistry and Geochronology, GEOKHI RAS, Russia
}

Isotopic signatures are used to distinguish Group I, Transition, and Group II kimberlites, and provide information on the origin of melts parental to the final intrusion. Kimberlitic rocks are often weathered and altered, making them potentially unsuitable for whole rock isotopic studies. We therefore have explored the alternative use of the isotopic signatures of resistant minerals in kimberlites including zircon, rutile and perovskite. These minerals also have the advanage of being amenable to rapid dating by the in situ LAICPMS technique (Cooper et al., this conference). The study by Mirnejad et al. (2003) shows altered lamproite whole rock samples, and the mineral phases clinopyroxene, apatite, perovskite, and potassic richerite are in isotopic equilbrium for lamproite. The relationship between the isotopic systems in these minerals and host kimberlites is reported in this study.

Lu-Hf isotopes have been determined by in-situ laser ablation MC-ICPMS on previously dated zircon and rutile from a range of kimberlites across South Australia (Cooper et al., this conference; Griffin et al., 2000). Sm-Nd isotopes were determined on whole rock samples from the Timber Creek kimberlites in Northern Territory of Australia, El Alamein, Pitcairn JS (176 $\pm 10 \mathrm{Ma})$ pipe from South Australia, and the Proterozoic diamondiferous Blacktop 01 kimberlite dyke in the Pilbara region of Western Australia. The diamondiferous Mileura 01 kimberlite dyke has not been dated, but is believed to be of similar emplacement age to the Nabberu kimberlites (1900Ma) located $460 \mathrm{~km}$ to the ENE on the Yilgarn Craton. Sm$\mathrm{Nd}$ data for the Nabberu kimberlite were reported by Graham et al. (1999). Southern African samples are represented by kimberlites from Orapa, Leicester and Monastery (80Ma).

The preliminary results for Australian samples indicate that whole-rock $\varepsilon N d$ (range from -6.3 to 1.4) and zircon $\varepsilon \mathrm{Hf}$ data plot close to the Mantle Array, showing an evolved signature compared to the Depleted Mantle. However, zircons in some kimberlites (Orapa, Leicester) show a large range in Hf-isotope composition compared to the whole-rock Sm-Nd data (Figure 1). Sr and Nd isotopic data for perovskite from South Australian kimberlites are in progress and will be reported in this paper. Preliminary plots are provided in Figures 2 and 3.

\section{References}

Graham, S., Lambert, D.D., Shee, S.R., Smith, C.B. and Hamilton, R., 1999. Re-Os and Sm-Nd isotopic Constraints on the Sources of Kimberlites and melnoites, Earaheedy Basin, Western Australia. In Proc. VII Int. Kimberlite Conference, Gurney, J.J., Gurney, J.L., Pascoe, M.D., \& Richardson, S.H., eds. 280-290.

Griffin, W. L., Pearson, N. J., Belousova, E. A., Jackson, S. R., van Achterbergh, E., O'Reilly, S. Y., \& Shee, S. R., 2000. The Hf isotope composition of cratonic mantle: LAM-MC-ICPMS analysis of zircon megacrysts in kimberlites. Geochim. Cosmochim. Acta, 64, 133-147.

Mitchell, R.H., 1995. Kimberlites, Orangeites, and Related Rocks. Plenum Press.

Mirnejad, H., Bell, K., \& Kjarsgaard, B., 2003. Sr and Nd isotopic geochemistry of Pegmatoid Laproites from Walgidee Hills, West Kimberley, Australia. Geological Society of America Abstracts wth Programs, 35. 325.

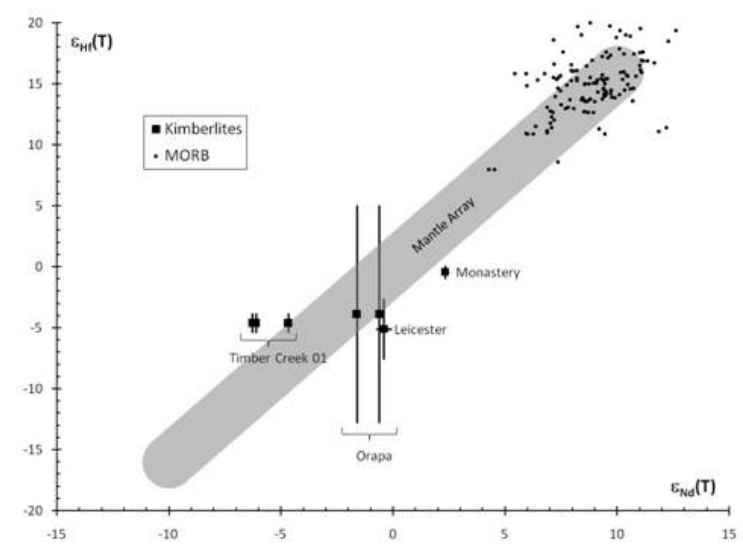

Figure 1. Zircon Hf isotopes and whole rock Nd isotopes for selected kimberlite, compared with MORB. 


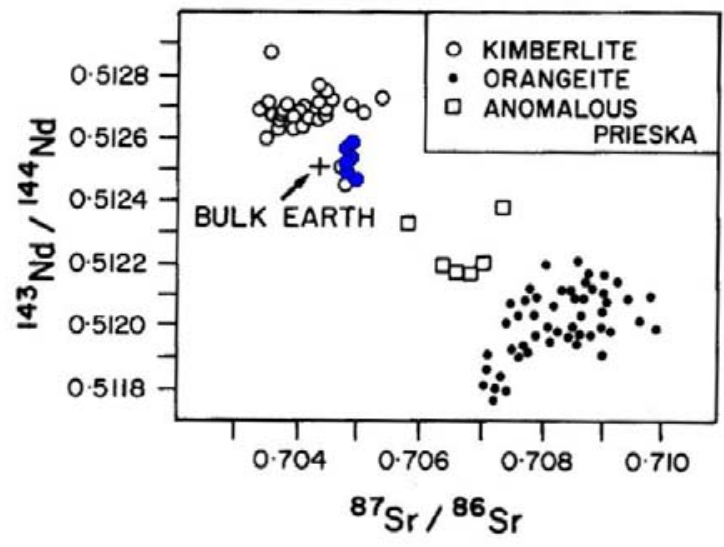

Figure 2. Sr-Nd isotopic ratio figure (from Mitchell, 1995) showing perovskite from Mt Hope 05 kimberlite (blue, $n=7$ ).

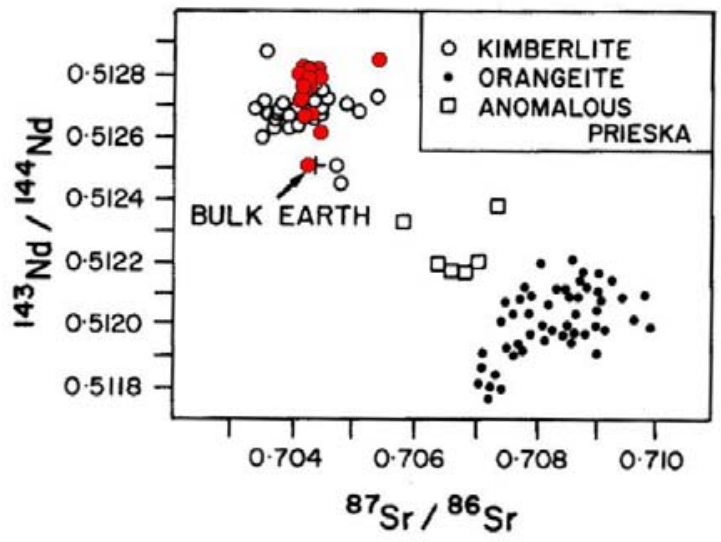

Figure 3. Sr-Nd isotopic ratio figure (from Mitchell, 1995) showing perovskite from FS66 kimberlite (red, n=18) 